\title{
PPP Projects: Improvements in Stakeholder Management
}

\author{
Chika Amadi a, Patricia Carrillo ${ }^{a}$, Martin Tuuli ${ }^{b}$ \\ a School of Architecture, Building and Civil Engineering, Loughborough University, Loughborough, \\ Leicestershire LE11 3TU United Kingdom \\ ${ }^{b}$ Ghana Institute of Management and Public Administration, Greenhill, Accra, Ghana \\ *P.M.Carrillo@lboro.ac.uk
}

\begin{abstract}
Purpose

The implementation of PPPs, particularly in low and middle-income countries, has been hampered by external stakeholders' opposition leading to failure of several projects. This paper aims to develop a framework to improve external stakeholder management in PPP projects.

Methodology

Two case studies consisting of 23 interviews with a wide range of internal and external stakeholders were employed. This was supplemented with a focus group approach to validate the framework.
\end{abstract}

\section{Findings}

A new framework for the management of external stakeholders is developed. It encompasses new features such as the dynamic identification of stakeholders at each project phase and their corresponding interests.

Research limitations/implications

The scope is road transportation projects in Nigeria and thus the recommendations may not be globally applicable. 
The findings can help the public sector and their agencies to manage external stakeholders and maintain successful relationships on PPP projects.

\section{Originality}

The paper contributes to existing knowledge in four key areas: (1) it confirms that the skill and actions of internal stakeholders are vital to the stakeholder management process; (2) it shows that one-off stakeholder identification proposed in literature is a flawed approach; (3) it proposes that the identification of external stakeholders' interests be dynamic; and (4) it adds the perspective of low and middle-income countries in stakeholder management in PPP projects.

\section{Introduction}

Governments worldwide have been using Public Private Partnerships (PPPs) as a way of addressing infrastructure gaps (World Bank, 2016). PPPs are "long-term contractual arrangements between a public sector entity and a private sector provider. The private sector provider is engaged to design, build, finance, maintain and operate infrastructure assets and related services. The risks associated with construction delay, cost overrun and maintenance of the asset are transferred to the private sector partner" (HM Treasury, 2018: p2). Whilst initially some reports praised the outcome of PPP projects (e.g. National Audit Office, 2009), in recent years, criticisms have appeared. For example, the National Audit Office (2018) states that whilst PPP have delivered on certainty of construction costs, improved operational efficiency and higher quality and well-maintained assets had not materialised. Internationally, Hodge and Greve (2007) provided highlights of both positive and negatives experiences in the USA and Australia. Despite its flaws, PPP continues to gain traction with governments. For example, in Sub Saharan Africa, most of the US\$93 B/year infrastructure deficit is expected to be provided by PPP (Olobo, 2016). Some of the PPP failures have been related to stakeholder management. For example, El-Gohary et al., (2006) highlighted cases of stakeholder opposition to PPP projects and Rwelamila et al. (2014) noted stakeholder rejection of the end-product of PPPs.

Although the stakeholder management approach has been available for several decades (Freeman, 1984), the issues with PPP projects have led to calls for a different type of stakeholder management process (Henjewele et al., 2013). For example, the Organisation for Economic Cooperation and Development (OECD) recommended that "public authorities 
should ensure adequate consultation with end-users and other stakeholders including prior to the initiation of an infrastructure project" (OECD, 2007:18). However, problems are occurring even in countries with mature stakeholder management and PPP processes. For example, due to public outrage at major PFI projects in the UK, Hansford (2018: 3) emphasised "there is a real need to make the public feel that projects are "done with them, not to them". Similarly, Whitelaw (2018:32) stressed the need for "Highways England to review the way it consults on road schemes to ensure a full range of options is included". Thus, the key issue appears to be when and how consultations take place.

This paper therefore aims to improve existing external stakeholder management processes. It does this by trying to understand the perspectives of both internal and external stakeholders within the context of road transportation projects in Nigeria, a low and middle-economy, relatively new to the PPP concept. The findings culminate in a proposed framework for stakeholder management.

\section{Stakeholder Management Theory}

The Stanford Research Institute introduced the concept of stakeholders in management literature in 1963 (Freeman, 1984). Thereafter, Freeman in the 1980s, proposed a strategic management framework, which provided the platform for stakeholder theory. Freeman stated that the 'new business environment' depended on both internal and external stakeholders and owners and employees should be considered as a "matter of everyday occurrence rather than an exception" (Freeman, 1984:7). This, he argued, became necessary because of the vital role each stakeholder group plays in the success of the business enterprise. Many scholars have built on the work of Freeman to advance stakeholder theory. Notably, Donaldson and Preston's (1995) work on stakeholder theory has been widely cited by scholars (Elias et al., 2002; Amaeshi, 2010). Donaldson and Preston (1995) divided the stakeholder concept into three different perspectives: instrumental; descriptive; and normative. The instrumental perspective seeks to establish a correlation between the achievement of an organisation's desired objectives such as profitability to stakeholder management. The descriptive perspective explores what organisations do, the methods and techniques employed in managing its stakeholders. Finally, the normative perspective considers persons or groups on ethical grounds; they have legitimate interests in an organisation and these interests are of intrinsic value (Donaldson and Preston, 1995).

However, stakeholder management theories according to Friedman and Miles (2002) have been approached typically from the perspective of business ethics, corporate governance and/or corporate social performance. This places the organisation at the centre of stakeholder 
analysis which discourages the consideration of stakeholders and this causes a biased view of the organisation-stakeholder relationship. This approach has not promoted healthy relationships among stakeholders in PPP projects but has led to the neglect of groups of stakeholders, particularly external stakeholders (Rwelamila et al., 2014). Henjewele et al. (2013) recommended a paradigm shift from the current position in which external stakeholders are excluded to a place of inclusion where they are involved in decision making. They further argued that the current arrangement in PPP schemes encourage the marginalisation of external stakeholders. The recognition of the rights and interests of external stakeholders are ethically correct because of the dual role they play; they are the final beneficiaries of the infrastructure and the related services and they are the main source of revenue.

\subsection{Stakeholder Management within the PPP Context}

Construction projects create a web of stakeholders with varying interests (Chinyio and Olomolaiye, 2010). These various stakeholders, internal to the project such as public and private project officials, and those external to the project such as local communities and endusers play important roles in the delivery of construction projects (Cleland and Ireland, 2007). To this end, studies have been conducted and strategies and processes developed to aid in managing stakeholders. Notable studies include frameworks developed by Karlsen (2002), Bourne and Walker (2006), Sutterfield et al. (2006), Cleland and Ireland (2007), Yang et al. (2014). There are overlaps in the steps recommended in the various frameworks.

Although recommendations in prior studies are helpful in managing stakeholders, their application in the PPP project environment becomes difficult due to the distinct characteristics of PPPs (De Schepper et al., 2014). Distinct characteristics of PPPs include: long term contracts (Smyth and Edkins, 2007); end-users are major financial contributors (Amadi et al., 2018); and complex, dynamic and role sharing relationship between project partners (Zou et al., 2014; De Schepper et al., 2014). A clear understanding of these PPP characteristics is important for the successful implementation of stakeholder management principles (Henjewele et al., 2013).

El-Gohary et al. (2006), Henjewele et al. (2013), and Ng et al. (2013) proposed frameworks for managing stakeholders within the PPP context. These include practical steps for engaging with stakeholders at different phases of PPP projects; some of which are similar to traditional public procurement stakeholder management. However, some characteristics of PPP such the dual stakeholder perspectives (De Schepper et al., 2014) in which the responsibilities of the public and private sector agencies in managing stakeholders in different phases of PPP projects are not considered in previous frameworks developed specifically for PPP. De 
Schepper et al. (2014) therefore recommend that stakeholder management should be approached from the dynamic dual stakeholder perspective where the partners partake in managing external stakeholders at the various phases of the project although they did not recommend processes for this. PPP project phases according to Joyner (2007) are critical and key actors in the partnership should deal with the multiplicity of interests from communities that might arise during community consultation processes.

Although the above frameworks are important, they have limitations and do not present a complete approach to address stakeholder management issues in PPP projects. For example, relationships between internal stakeholders in PPPs are complex (Zou et al., 2014) and change over the course of projects. To this end, the responsibilities of internal stakeholders in managing external stakeholders are missing in existing frameworks. Therefore, a structure for responsibility sharing among the internal stakeholders in stakeholder management in PPP project requires further study (De Schepper et al., 2014). Existing frameworks do not consider the knowledge of internal and external stakeholders in all the phases of PPP. Although EI Gohary et al. (2006) recognised the importance external stakeholders' awareness of PPP, their framework is designed to involve stakeholders at the early phases of PPP and not the entire PPP process. Additionally, internal stakeholders' knowledge is not considered. For a developing country with nascent PPP experience, the knowledge of internal stakeholders, particularly the public sector officials are limited and requires improvement. Hence, there is the need to integrate these studies to develop a new approach to stakeholder management within the PPP context. Furthermore, these studies are within high-income countries context with greater PPP maturity markets and structures and political stability compared to many low and middle-income countries such as Nigeria. Rowlinson et al., (2010) advocated the importance of considering the context specific nature of stakeholder management and Rwemaila et al., (2014) stressed the importance of studying stakeholder management in PPP projects in low and middle-income countries where stakeholders' opposition to PPP projects is frequent and where the public-sector agencies are bureaucratic and less attuned to addressing external stakeholders' needs.

Based on the above arguments, the research objectives of the study were aimed at answering:

1. What are the perceptions of PPP stakeholder management from both internal and external stakeholders?

2. What processes are used for stakeholder identification and how are their interests determined and prioritised?

3. How was communication and interaction between and within internal and external stakeholders managed? 


\section{Research Methods}

This research adopted an abductive approach; this combines both the inductive approach (theory to observation) and a deductive approach (observation to theory) (Robson, 2011). The research methods adopted comprised of (1) a review of literature, (2) case studies and (3) focus group meetings. The literature review was used to understand the key issues of stakeholder management theory and explore the extent to which these were relevant to the PPP context. This resulted in the development of a conceptual framework that was then used to collect data. Case study data was collected using semi-structured interviews, document analysis and direct observation. The findings were synthesised into a framework which was then validated in focus group meetings with industry professionals.

\subsection{Case Studies}

Proverb and Gameson (2008) suggest that case study research is relevant to industries that are driven by projects with different types of organisations. Yin (2014) also identified case study research as suitable for examining contemporary events. In this context they were used to investigate stakeholder management in PPP from the perspectives of different organisations and groups of stakeholders.

\subsubsection{Case Selection}

The cases were both PPP tolled road transportation projects in Nigeria at different project phases with different perceptions of success. These were selected based on their relevance to the study of stakeholder management (Eisenhardt, 1989) and three factors. Firstly, they were based in a low and middle-income country with access to data. Rwemaila et al. (2014) and El-Gohary et al. (2006) identified opposition to PPP projects are most frequent in low and middle-income countries. Secondly, road transportation projects receive wide publicity because their development usually affects a vast amount of land and property (South et al., 2015). Thirdly, PPP tolled road transportation projects are an example of a user-type PPP scheme where users pay directly for using a facility. Moreover, stakeholders' opposition to PPP projects are common in user-type PPPs (El-Gohary et al. 2006).

Both case studies used a Design, Build, Finance and Operate and Transfer (DBFOT) model. Case Study 1 is a major road project and has generated a lot of public opposition and protests (Njoku et al., 2011). It is on a brownfield site, has a major impact on the local community and is currently in operation. Case Study 2 is a bridge project; it includes approach roads with six 
traffic lanes. The project is on a greenfield site and is currently at the construction phase. This project was widely accepted by the local community (Okocha et al., 2014).

\subsubsection{Interviews}

Interviews were the main data collection method in the case studies and were used to investigate the interactions between stakeholders and how they related with each other (Yin, 2014). Semi-structured interviews were used because of its flexibility as it gave the opportunity to seek further clarification (Robson, 2011). Semi-structured interviews have also been used in similar studies on stakeholder management such as $\mathrm{Ng}$ et al. (2013). Ten indepth interviews were conducted for Case Study 1 and thirteen for Case Study 2 as shown in Table 1. The number of interviews conducted was influenced by covering a range of different perspectives and achieving saturation in the information (i.e. a point where information being gathered became repetitive). A stratified sampling was combined with snowball sampling to achieve the desired coverage. The interviewees were involved in various stakeholder management processes at different phases of the project such as planning, procurement and construction. In addition, the external stakeholders were community, trade union and human right activist leaders and they liaise and act as middlemen between their communities, unions and the internal stakeholders at different phases of the projects for several years. 
Table 1: Details of Case Study Interviewees

\begin{tabular}{|c|c|c|}
\hline Interviewee & $\begin{array}{c}\text { Type of } \\
\text { Stakeholder }\end{array}$ & Number of Interviews \\
\hline \multicolumn{3}{|c|}{$\begin{array}{ll}\text { Case Study 1: A major road project } \\
\end{array}$} \\
\hline $\begin{array}{l}\text { Senior public-sector officials } \\
\text { (2 State PPP officers, } 1 \text { Ministry of } \\
\text { Environment, } 1 \text { Ministry of Physical } \\
\text { Planning and Urban Development) }\end{array}$ & Internal & 4 \\
\hline $\begin{array}{l}\text { Senior private sector official } \\
\text { (1 SPV representative) }\end{array}$ & Internal & 1 \\
\hline $\begin{array}{l}\text { Members of local community } \\
\text { ( } 4 \text { community representatives and } \\
\text { former chairman of Community } \\
\text { Development Authority), }\end{array}$ & External & 5 \\
\hline \multicolumn{3}{|c|}{$\begin{aligned} \text { Case Study 2: A bridge project } \\
\end{aligned}$} \\
\hline $\begin{array}{l}\text { Senior public-sector officials } \\
\text { ( } 2 \text { Director of Ministry of Works and } \\
\text { Ministry of Environment and } 2 \\
\text { Infrastructure Commission officers, }\end{array}$ & Internal & 4 \\
\hline $\begin{array}{l}\text { Senior private sector officials } \\
\text { (Public Relations official, main } \\
\text { contractor) }\end{array}$ & Internal & 1 \\
\hline $\begin{array}{l}\text { Members of Local Community } \\
\text { (Local community chief and } 4 \\
\text { community representatives) }\end{array}$ & External & 5 \\
\hline $\begin{array}{l}\text { Trade union member } \\
\text { ( } 2 \text { Chairmen of maritime and Transport } \\
\text { Workers unions) }\end{array}$ & External & 2 \\
\hline $\begin{array}{l}\text { Human rights group member } \\
\text { (Human Rights Association) }\end{array}$ & External & 1 \\
\hline \multicolumn{2}{|l|}{ Total } & 23 \\
\hline
\end{tabular}

The literature review revealed the key failings of current stakeholder management processes in terms of how stakeholders were engaged, when they were engaged and how. Thus, the interview questions explored the following themes:

- Purpose of engaging stakeholders;

- $\quad$ Processes for stakeholder identification;

- Processes for engagement; and

- Evaluation of stakeholder management processes.

In addition, relevant documents such as minutes of meetings, environment and social impact assessment reports, stakeholder committee reports, official memos, PPP policy documents and direct observation complemented the interviews within the case studies. The data from these methods were analysed and used in the development of the framework. Data gathered in this study were condensed by coding in NVivo 10. Recurring or common key words and phrases from both the interviews and documentary evidence were selected and grouped into themes. 


\subsection{Focus Groups}

Focus groups were used to validate the framework from the perspective of different stakeholders (Bryman, 2008). The focus group methodology was selected to elicit the collective views of PPP professionals and to promote sense-making produced collectively as advocated by (Wilkinson, 1998). Focus groups have been used in previous studies to validate frameworks and models (e.g. Carrillo et al., 2006 and $\mathrm{Ng}$ et al., 2013). Two focus groups were held with public and private sector organisations, the two main players often involved in a PPP arrangement and therefore in a good position to comment on the usefulness of any framework developed. These organisations were not part of the case studies but were used to ensure objectivity and to enhance external validity. The first focus group was with a public-sector organisation responsible for supervising and regulating PPP projects in Nigeria. This group represents one of four PPP public-sector organisations with this responsibility and consisted of an Executive Director, his Special Assistant, two Directors, a Project Analyst and three Project Officers. The second focus group was with a private-sector organisation that is currently procuring a PPP project in Nigeria and consisted of the Chairman and the Senior Finance Officer. Although a small number of participants, PPP is new to Nigeria and the number of professionals with adequate knowledge of PPP is limited. These two participants however have in-depth experience with PPP to make their views pertinent on the feasibility and usefulness of the framework.

The focus group process consisted of: (1) presenting the aim of the research; (2) explaining the research methods adopted and how the framework was developed; (3) a discussion on each of the framework's elements and how these should be used; and (4) a question and answer session. Following this, each participant was asked to complete a questionnaire. The questionnaire allowed the participants to reflect on the framework and document their views individually in a structured manner under four headings including: (1) Overall assessment of the framework; (2) Completeness of the framework; (3) Practicality of the framework; and (4) User friendliness of the framework. Details of the questions asked are included in Section 6 and Table 5. Ten questionnaires were issued to the participants after the workshop to provide additional information; eight were returned.

\section{Findings and Discussion}

The findings from the study are grouped under the following four themes. 


\subsection{Purpose of engaging stakeholders}

The purpose for stakeholder management answers "the what and why" questions. The internal stakeholders had several rationales for stakeholder management for example:

"part of the feasibility study because you want to know first of all if the people want the service and if they want the service can they afford it?. so that their views could be incorporated in the project"

Other reasons include: to comply with regulations; to appease the external stakeholders; to build relationships; and to partner with external stakeholders. These are consistent with some of the rationales identified in previous studies such Close and Loosemore (2014). The findings indicated that external stakeholders either supported or opposed the project based on their perception of internal stakeholders' motive for engaging them. Table 2 shows the views of the two groups towards stakeholder engagement.

Table 2: Rationales and perceptions of stakeholder management

\begin{tabular}{|l|l|l|}
\hline Project Case Study & \multicolumn{1}{|c|}{ Internal Stakeholders Rationale } & External Stakeholders Perception \\
\hline $\begin{array}{l}\text { Case Study 1 } \\
\text { (road project) }\end{array}$ & $\begin{array}{l}\text { 1. Compliance with regulations } \\
\text { 2. Enhance project buy-in }\end{array}$ & $\begin{array}{l}\text { 1. Viewed internal stakeholders' } \\
\text { intention as not genuine }\end{array}$ \\
\cline { 2 - 3 } & $\begin{array}{l}\text { 3. Partnership with external } \\
\text { stakeholders }\end{array}$ & $\begin{array}{l}\text { 2. Open to partnership with internal } \\
\text { stakeholders }\end{array}$ \\
\hline $\begin{array}{l}\text { Case Study 2 } \\
\text { (bridge project) }\end{array}$ & $\begin{array}{l}\text { 1. Compliance with regulations } \\
\text { 2. Ensure smooth project delivery } \\
\text { 3uild relationship with external } \\
\text { stakeholders }\end{array}$ & $\begin{array}{l}\text { 1. Relief to the traffic on existing } \\
\text { bridge } \\
\text { 2. Economic development of their } \\
\text { communities }\end{array}$ \\
\hline
\end{tabular}

Thus, although both case studies had near identical rationales, the perceptions of the external stakeholders were very different.

\subsection{Processes for stakeholder identification}

The findings show that there are two stakeholder identification steps: internal stakeholder identification; and external stakeholder identification. 


\subsubsection{Identification of internal stakeholders}

Internal stakeholders are not a single entity but independent and fragmented. Emphasis in existing literature has however been on the identification of external stakeholders as internal stakeholders are perceived as a single entity (De Schepper et al, 2014). Furthermore, identification was not a one-off event; as new internal stakeholders were identified in the later phases of Case Study 1, new interests of external stakeholders were identified which were not previously captured.

\subsubsection{Identification of external stakeholders}

Case Study 1 revealed that external stakeholders were identified early in the project lifecycle based on the project location and were made up of land and property owners, local communities, trade unions and human rights group around the project corridor.

"Communities along that axis, some of the communities include ...; others I may not be able to mention all of the names now, were consulted by the consultant"

(Public Official 3, Case Study 1).

They sent a message round that those owning property along that line should come"

(Community Chief, Case Study 2)

The identification of these stakeholders was not a one-off exercise but continued throughout the course of the project. The continuous identification of stakeholders was due to the rapid development of the corridor around the project. This dynamic identification of stakeholders contrasts with existing frameworks that suggest one-off identification of stakeholders.

\subsubsection{Dynamic determination of stakeholders' interests}

Both cases show that the interests of the external stakeholders were dynamic and varied within a phase and across the various project phases.

"Some things don't come to the fore until you start [construction]"

(Public Official 1, Case Study 1).

Moreover, in Case Study 1, during the protests, the interest of external stakeholders was 'no tolling'. After the protests, this became 'no fencing' of the road median with bricks (the original design) and safety concerns (this led to the construction of pedestrian bridges). The change of interests over time is consistent with views expressed by Olander (2007). Table 3 shows 
how the external stakeholders' interests changed during the project life cycle. However, there was no structured way of mapping these interests to the appropriate internal stakeholders.

Table 3: Cross-case dynamic interests of external stakeholders

\begin{tabular}{|l|l|l|l|l|}
\hline \multirow{2}{*}{ Project Phase } & \multicolumn{2}{|l|}{ Case study 1 (road project) } & \multicolumn{2}{l|}{ Case study 2 (bridge project) } \\
\cline { 2 - 5 } & Initial Interests & New Interest & Initial Interests & New Interests \\
\hline Development & Land acquisition & $\begin{array}{l}\text { Payment of } \\
\text { compensation }\end{array}$ & Land acquisition & $\begin{array}{l}\text { Payment of } \\
\text { compensation }\end{array}$ \\
\hline Construction & $\begin{array}{l}\text { Land acquisition } \\
\text { Payment of } \\
\text { compensation }\end{array}$ & $\begin{array}{l}\text { - Fencing of } \\
\text { the road } \\
\text { maiden. } \\
\text { Access to } \\
\text { property }\end{array}$ & $\begin{array}{l}\text { - Payment of } \\
\text { compensation. } \\
\text { Safety } \\
\text { concerns }\end{array}$ & Employment \\
\hline $\begin{array}{l}\text { Operation and } \\
\text { Maintenance }\end{array}$ & No tolling & $\begin{array}{l}\text { Cancellation } \\
\text { of second toll }\end{array}$ & $\begin{array}{l}\text { This phase not } \\
\text { yet reached. }\end{array}$ & \\
\hline
\end{tabular}

This therefore highlights the need for a mechanism to periodically assess external stakeholders' interests and ensure the corresponding internal stakeholder has been identified to deal with that interest.

\subsection{Processes for engagement}

The case study findings identified who took the lead in stakeholder engagement and how it took place are as below.

\subsubsection{Roles and responsibilities}

The role of the internal stakeholders in managing the external stakeholders varied during the project lifecycle. For example, during the project development phases for both case studies, the internal stakeholder (i.e. the public sector) was solely responsible for stakeholder management because the Special Purpose Vehicle (SPV) had not yet been selected. After the selection of the SPV, stakeholder management became a joint responsibility between the public sector and the SPV.

The internal stakeholders employed different strategies to engage external stakeholders.

"There are some [stakeholders] you have to go to the press, some you have to roll out programmes, do jingles on the radio and TV, some you have to use the newspapers, some you call town hall meetings, some you have to do one- one, in fact most of them you have to do one-on-one, some you have to send email to organisation inviting for meeting" 
(SPV Official, Case Study 1)

"They opened up how far they have gone. They televised it on video system place on a blank board. So we witnessed how far they have gone, how the roads from the swampy area, how the roads will be hung and how motorists will be travelling on it"

(Human Rights representative, Case Study 2)

The main strategies were negotiation, concessions and trade-offs, which agree with those recommended by Chinyio and Akintoye, (2008). In addition, internal stakeholders used coercion on Case Study 1 and this was counterproductive and resulted in further protests.

\subsubsection{Communication format and channels}

Al-Khafaji et al. (2010) highlighted the means to communicate with stakeholders varies from one stakeholder to another. The internal stakeholders used different formats and channels to communicate with external stakeholders. For example, in Case Study 2, the project information was translated and printed in local dialects to communicate with members of the local communities who were not proficient in the English language. Also, during meetings, internal stakeholders communicated with the local communities in their native dialects through a translator.

"Their approach was very friendly... It was a friendly approach. But the main issue is that they took cognisance of all that attended the meeting"

(Human Rights representative, Case Study 2)

This supports Manowong and Ogunlana's (2010) assertion that communication in stakeholder management should be flexible and can either be formal or informal, written or verbal. Also, the means of communication adopted depended on the types of stakeholder and issues. For example, property owners were contacted and visited individually by internal stakeholders and via letters to address issues on compensation.

\subsubsection{Capacity of the stakeholders}

Case Study 1 highlighted that both the internal and external stakeholders lacked skills in stakeholder management and this led them to make wrong choices, resulting in external stakeholders' opposition to the project. For example, in some instances where dialogue and persuasion were required, force was used; this escalated the situation resulting in protests and disruption of the project. Case Study 1 also showed that opposition to the project was due 
to ignorance and lack of understanding of the PPP scheme due to its novelty in Nigeria. However, Case Study 2 had a different outcome because the external stakeholders, through the efforts of the internal stakeholders, had a much better understanding of PPP and its consequences; this resulted in a much better partnership relationship.

\subsection{Evaluation of the management process}

Two key areas were deduced from the findings; these were the need to assess the engagement activities undertaken and identify problem areas.

Findings from both case studies indicate that there were no formalised means for evaluating stakeholder management activities.

"We don't have any structure that was put in place that we automatically get feedback from"

(Public Official 1, Case Study 1).

"Not [a feedback mechanism] officially on this project. Normally, we always create that device but not yet on this project. The only means is their reaction to know the way they react"

(SPV Official, Case Study 2)

This conflicts with guidance from the stakeholder management literature such as Karlsen (2002) and Sutterfield et al., (2006). However, internal stakeholders recognised the need for a structured mechanism. Based on the case study findings, much work needs to be done to provide further guidance within the context of PPP stakeholders in the low and middle-income country context. The main requirements of such a framework from the findings can be summarised as follows:

- To agree the purpose of stakeholder management;

- To identify internal and external stakeholders;

- To map the interests of external stakeholders onto internal stakeholders and systematically review these interests;

- To propose various communication strategies for both internal and external stakeholders to interact with each other effectively;

- $\quad$ To improve the stakeholder management capacity of the internal stakeholders and PPP knowledge of external stakeholders; and

- $\quad$ To evaluate the success of the stakeholder management process. 
A key finding is that all these processes need to occur continually throughout the project hence it is proposed that the these are aligned to the PPP project phases.

\section{Framework Development and Description}

Based on the findings discussed in Section 4, a framework for stakeholder management in PPP projects was developed. It consists of six steps as shown in Table 4. Column 1 identifies the requirements of the framework as synthesised jointly from the literature (Section 2) and the case study findings (Sections 4). Column 2 (Stakeholder Management Steps) are structured steps to address the requirements identified in Section 4. Column 3 (Key Activities (Who)) are the individual tasks that need to be completed and by whom taking cognisance of De Schepper et al.'s dual responsibility recommendations.

Table 4: Case Studies' Findings and Proposed Stakeholder Management Steps

\begin{tabular}{|c|c|c|}
\hline $\begin{array}{l}\text { Key Findings from Case } \\
\text { Studies }\end{array}$ & $\begin{array}{c}\text { Stakeholder Management } \\
\text { Steps }\end{array}$ & Key Activities (Who) \\
\hline $\begin{array}{l}\text { To agree the purpose of } \\
\text { stakeholder management }\end{array}$ & $\begin{array}{l}\text { 1: Determine the purpose of } \\
\text { stakeholder management }\end{array}$ & $\begin{array}{l}\text { - Agree the purpose for } \\
\text { stakeholder management (IS) } \\
\text { - Determine how this will be } \\
\text { achieved (IS) } \\
\text { - Identify potential outcomes (IS) }\end{array}$ \\
\hline $\begin{array}{l}\text { To identify internal and } \\
\text { external stakeholders }\end{array}$ & 2: Identify stakeholders & $\begin{array}{l}\text { - Identify internal stakeholders } \\
\text { (IS) } \\
\text { - Identify external stakeholders } \\
\text { (IS) }\end{array}$ \\
\hline $\begin{array}{l}\text { To map the interests of } \\
\text { external stakeholders onto } \\
\text { internal stakeholders. } \\
\text { To systematically review the } \\
\text { interests of existing and new } \\
\text { external stakeholders. }\end{array}$ & $\begin{array}{l}\text { 3: Determine external } \\
\text { stakeholders' interests }\end{array}$ & $\begin{array}{l}\text { - Identify external stakeholders' } \\
\text { interests (IE and ES) } \\
\text { - Map external stakeholders' } \\
\text { interests against internal } \\
\text { stakeholders (IS) } \\
\text { - Systematically check for new } \\
\text { external stakeholders' interests } \\
\text { (IS and ES) }\end{array}$ \\
\hline $\begin{array}{l}\text { To propose various } \\
\text { communication strategies for } \\
\text { both internal and external } \\
\text { stakeholders }\end{array}$ & $\begin{array}{l}\text { 4: Develop a communication } \\
\text { strategy }\end{array}$ & $\begin{array}{l}\text { - Identify and establish } \\
\text { communication channels } \\
\text { between and within stakeholder } \\
\text { groups (IS and ES) } \\
\text { - Conduct a KAP survey*(IS) } \\
\end{array}$ \\
\hline $\begin{array}{l}\text { To improve the capacity of } \\
\text { both the internal (stakeholder } \\
\text { management) and external } \\
\text { (PPP knowledge) } \\
\text { stakeholders }\end{array}$ & $\begin{array}{l}\text { 5: Determine capacity building } \\
\text { strategies }\end{array}$ & $\begin{array}{l}\text { - Improve internal stakeholders' } \\
\text { capacity (IS) } \\
\text { - Improve external stakeholder } \\
\text { capacity (IS and ES) }\end{array}$ \\
\hline $\begin{array}{l}\text { To evaluate the success of } \\
\text { the management process }\end{array}$ & $\begin{array}{l}\text { 6: Evaluate the stakeholder } \\
\text { management processes }\end{array}$ & $\begin{array}{l}\text { - Evaluate the stakeholder } \\
\text { management steps (IS) }\end{array}$ \\
\hline
\end{tabular}

Key:

IS = Internal stakeholders

ES $=$ External stakeholders 
${ }^{*} \mathrm{KAP}=$ Knowledge, Attitudes and Practices; an addition based on Framework Evaluation (Section 6).

Each step shown in Table 4 is described below. However, a much more detailed explanation will be provided for Step 3: Determine Stakeholders' Interest as this is considered a unique contribution is added to stakeholder management theory for PPP in the low and middle-income country context.

\section{Step 1: Determine the purpose of stakeholder management}

This step identifies internal stakeholders' motives and objectives of what the stakeholder management exercise sets out to achieve. This step is initiated at the beginning of the PPP scheme. The overarching rationale should be to build a partnership relationship with the external stakeholders. The purpose of this is to enhance support, buy-in and give external stakeholders a sense of belonging as part-owners of the project, because the feeling of marginalisation has been the main cause of stakeholders' opposition and protests against PPP projects (El Gohary et al., 2006; Rwelamila et al., 2014). This responsibility lies mainly with the internal stakeholders to identify what they wish to get out of the engagement process.

\section{Step 2: Identify Stakeholders}

This step consists of two activities as shown in Table 4 to reflect the interactions during the engagement processes. Stakeholder engagement is a partnership between both parties and thus the activities reflect the need to identify all impacted parties. This consists of identifying the internal stakeholders (e.g. public agencies and SPV) and external stakeholders (e.g. community representative, local trade unions, retailers, etc.). The process of identifying external stakeholders started with responsible internal stakeholder establishing the scope and the location of the project. This helped in identifying the local communities, cultural associations, potential end users of facility, and trade unions around the project vicinity. Methods used included site visits, town hall meetings, surveys, notices of property acquisition, TV and radio advertisements.

\section{Step 3: Determine external stakeholders' interests}

Section 2.2 identified few stakeholder management frameworks have focused on PPP and the key shortcoming was the determination of stakeholders' interests. A new framework will need to systematically review the changing interests of stakeholders as the project progresses. This conflicts with existing literature which advocates a single point to identify 
stakeholders, their interests and needs. The external stakeholders' interests are prioritised based on the interests that are most likely going to affect the progress of the project. In the case studies, as the project moved from development to construction and operation, different external stakeholders were identified who would not have been conceived in the project development stage. For example, as the road construction developed, this attracted further community development along the road alignment and the views of these new communities also needed to be considered. It is therefore recommended that stakeholder interests are reviewed at the start of each PPP project phase. For this reason, this step will be examined in more detail in Figure 1 to show its three constituent activities.

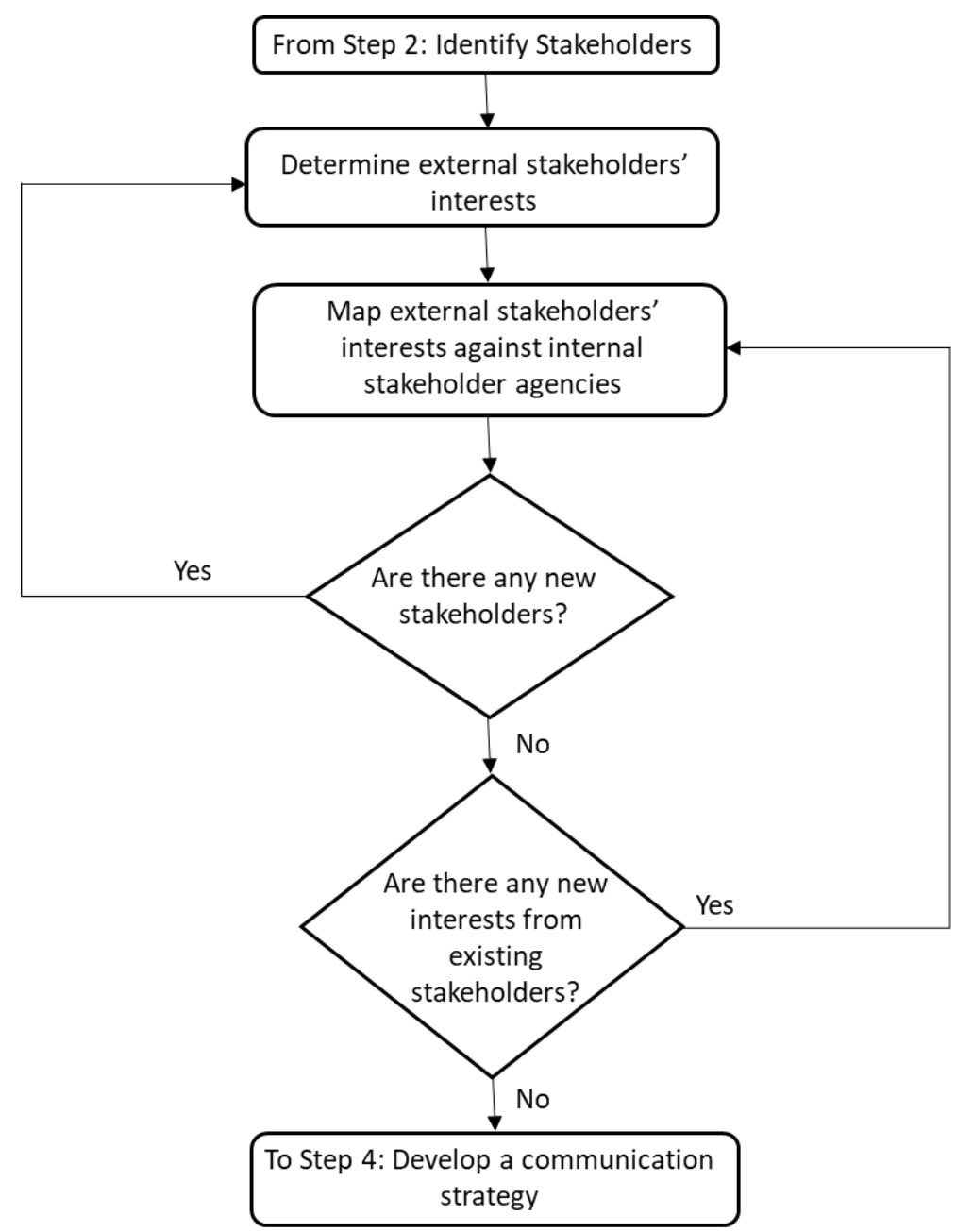

Figure 1: Step 3 Determination of external stakeholders' interests

1. Determine external stakeholders' interests. This activity aims to identify and collate the interests of various external stakeholders at the various project phases.

2. Map external stakeholders' interests against internal stakeholder agencies. This activity addresses the issue of "who is responsible for external stakeholders' specific interests?". 
It focuses on assigning external stakeholders' interests to the right internal stakeholder. For example, external stakeholders with land acquisition interests could be grouped and representatives of the agency responsible for land and property are assigned this responsibility.

3. Systematically check for new external stakeholders' interests and update mapping. This is achieved by anticipating and reviewing the interests of external stakeholders. This is depicted in the two decision boxes in Figure 1. It checks for new stakeholders and previously identified stakeholders that might have new interests as the project develops (e.g. local employment on the project). This activity takes place at the project development phase and is repeated at the start of each project phase. After the selection of the SPV, it comprises reviewing and updating interests that need to be addressed by multiple internal stakeholders. This is the responsibility of the SPV on behalf of all internal stakeholders.

\section{Step 4: Develop a communication strategy}

This step recognises that communication is key to the stakeholder management process because it helps in building and maintaining good relationships with its stakeholders (AlKhafaji et al., 2010). It is important to acknowledge that communication channels recommended for developed economies may not be appropriate for low and middle-income economies. Thus, both sets of stakeholders must agree on how best to communicate. For example, for Case Study 2, the preferred mechanism for communications was through a liaison committee comprising selected representatives from the various communities impacted by the project and internal stakeholders.

The second activity in this step comprises "Conduct a KAP". KAP stands for Knowledge, Attitudes and Practices. The KAP survey is used to study a specific population to gather information about what is known, believed and done about a topic. It helps in planning, implementing and evaluating topics under consideration (World Health Organisation, 2008). This was a new addition based on the framework's evaluation and will be discussed in Section 6.

\section{Step 5: Determine capacity building strategies}

Given that PPP is a new form of procurement to this context, both internal and external stakeholders would benefit from building their capacity by having a greater understanding of the PPP form of contract and their roles and responsibilities at different project phases. For example, section 4.3.3 identified that inappropriate and aggressive strategies were used and there was a lack of understanding of PPP by both stakeholders. This capacity can be built 
through strategies such as open/public forums, seminars, information leaflets on PPP, greater engagement in the PPP process, etc.

\section{Step 6: Evaluate stakeholder management process}

This step seeks to review and improve the process of engaging stakeholders and ensure the transfer of lessons learned at both intra and inter project level. Moreover, the long-term nature of PPP schemes, particularly the timeframe between project phases, makes it particularly important to evaluate the above steps at each new project phase.

\section{Framework Validation}

The purpose of the validation was to improve the framework by integrating industry practitioners' observations, suggestions and recommendations and to ensure external validity of the framework. The framework was not tested in a PPP project in Nigeria because PPP in Nigeria is still in its infancy with most of the projects still in the construction phase.

The framework for stakeholder management on PPP projects was validated using two focus groups consisting of 10 professionals from both internal and external stakeholder organisations as outlined in Section 3.2. There were no major disagreements on the framework from the internal and external stakeholders' perspectives. Overall, the research participants gave positive feedback on the framework, commending it to be suitable in mitigating opposition and promoting healthy stakeholder relationship in PPP projects.

A questionnaire survey was used to supplement the focus groups' discussion. Eight responses were received from the 10 participants. The questionnaire consisted of ten Likertscale questions and five open-ended questions under four headings: (1) Overall assessment of the framework; (2) Completeness of the framework; (3) Practicality of the framework; and (4) User friendliness of the framework. The framework received highly favourable ratings under all headings. The results are shown in Table 5 and indicate the number of responses for each question. 
Table 5: Results from Validation

\begin{tabular}{|c|c|c|c|c|}
\hline Validation Criteria & \multicolumn{4}{|c|}{ Overall Assessment of the framework } \\
\hline $\begin{array}{l}\text { Importance of the elements of } \\
\text { the framework }\end{array}$ & $\begin{array}{l}\text { Extremely } \\
\text { important } \\
87.5 \%\end{array}$ & $\begin{array}{l}\text { Important } \\
12.5 \%\end{array}$ & $\begin{array}{l}\text { Unimportant } \\
0 \%\end{array}$ & $\begin{array}{l}\text { Extremely } \\
\text { unimportant } \\
0 \%\end{array}$ \\
\hline $\begin{array}{l}\text { Ease to understand the } \\
\text { framework }\end{array}$ & $\begin{array}{l}\text { Extremely } \\
\text { easy } 0 \%\end{array}$ & Easy $87.5 \%$ & Difficult $12.5 \%$ & $\begin{array}{l}\text { Extremely } \\
\text { difficult } 0 \%\end{array}$ \\
\hline Validation Criteria & \multicolumn{4}{|c|}{ Practicality of the framework } \\
\hline Practicality of the framework & $\begin{array}{l}\text { Extremely } \\
\text { practicable } \\
12.5 \%\end{array}$ & $\begin{array}{l}\text { Practicable } \\
87.5 \%\end{array}$ & $\begin{array}{l}\text { Impracticable } \\
0 \%\end{array}$ & $\begin{array}{l}\text { Extremely } \\
\text { impracticable } \\
0 \%\end{array}$ \\
\hline $\begin{array}{l}\text { Suitability of framework in } \\
\text { addressing current } \\
\text { stakeholder management } \\
\text { issues }\end{array}$ & $\begin{array}{l}\text { Extremely } \\
\text { suitable } 25 \%\end{array}$ & $\begin{array}{l}\text { Suitable } \\
75 \%\end{array}$ & $\begin{array}{l}\text { Unsuitable } \\
0 \%\end{array}$ & $\begin{array}{l}\text { Extremely } \\
\text { unsuitable } \\
0 \%\end{array}$ \\
\hline $\begin{array}{l}\text { Relevance of the project } \\
\text { phases to the framework }\end{array}$ & $\begin{array}{l}\text { Extremely } \\
\text { relevant } 87.5 \%\end{array}$ & $\begin{array}{l}\text { Relevant } \\
12.5 \%\end{array}$ & $\begin{array}{l}\text { Irrelevant } \\
0 \%\end{array}$ & $\begin{array}{l}\text { Extremely } \\
\text { irrelevant } 0 \%\end{array}$ \\
\hline Validation Criteria & \multicolumn{4}{|c|}{ Completeness of the framework } \\
\hline $\begin{array}{l}\text { Completeness of the } \\
\text { elements of the framework }\end{array}$ & $\begin{array}{l}\text { Extremely } \\
\text { complete } \\
0 \%\end{array}$ & $\begin{array}{l}\text { Complete } \\
62.5 \%\end{array}$ & $\begin{array}{l}\text { Somewhat } \\
\text { complete } 27.5 \%\end{array}$ & $\begin{array}{l}\text { Extremely } \\
\text { incomplete } \\
0 \%\end{array}$ \\
\hline Elements to be added & \multicolumn{4}{|c|}{$\begin{array}{l}\text { Knowledge Attitude and Practice (KAP) }(87.5 \%) \text { and Cost } \\
\text { Component }(12.5 \%)\end{array}$} \\
\hline Elements to be removed & \multicolumn{4}{|l|}{ None } \\
\hline
\end{tabular}

The participants in the focus group meeting and the questionnaire respondents unanimously recommended that a "Knowledge, Attitudes and Practices (KAP) survey" be added to the framework. This was subsequently added to Step 4: Develop a Communication Strategy as shown in Table 4. Although the KAP survey is predominantly used in public health, its principles are relevant and can be applied in construction projects albeit with some modifications particularly due to novelty of the PPP scheme. For example, "Practices" can be modified and interpreted as not just "what is done or being done" but "what can be done" about 
PPP. This modification is necessary because a PPP project might not have been operational to measure and evaluate the users' practice regarding the PPP facility.

\section{Implications of the Framework}

This study has important practical implications for managing stakeholders in PPP projects. It provides a holistic approach to proactively manage stakeholders throughout PPP project phases. Firstly, the findings verify that internal stakeholders' skills with managing external stakeholders influence the outcome of stakeholder management exercises. These skills are vital to garner the support of external stakeholders, which is required for successful PPP project outcomes. Considering its importance, it therefore implies that stakeholder management skills emerges as a key criterion for selecting a SPV during the project procurement phase.

Secondly, one-off stakeholder identification in existing literature is a flawed stakeholder management approach. Dynamic stakeholder identification represents a more comprehensive approach that is capable of preventing the exclusion of stakeholders and thereby reducing opposition to PPP projects.

Thirdly, as highlighted in Step 3, Determine external stakeholders' interests, it is vital that the identification of this constituent's interest is repeated systematically at the start of each project phase. New stakeholders become relevant and indeed the interests of existing stakeholders change as the project progresses. Thus, it is important that these interests are continuously updated and mapped against the internal stakeholders for them to address.

Finally, this study adds the perspective of low and middle-income countries to stakeholder management in PPP projects. As Osei Kyei and Chan $(2016 ; 179)$ points out, "every first transport PPP project in Sub Saharan Africa attracted some form of protest". This study deepens our understanding of stakeholder management in PPP projects and expands the scope of the subject that has been limited to high-income countries context. Also, this study adds empirically to the growing body of knowledge on the relevance and applicability of stakeholder management principles in PPP projects across different countries.

\section{Limitations of the Framework}

Despite the favourable feedback from validation, there are limitations of the framework; mainly in terms of scope. The research is limited to two case studies in Nigeria and therefore may be applicable to a specific geographical context. Future research could extend this to other low 
and middle-income countries to determine differences and similarities. Further, the research is limited to the road transportation sector and other sectors' peculiarities are not necessarily accommodated in the framework. Hence, research should be replicated in other sectors such as education, health, energy, etc. Finally, testing the framework in a real world scenario was difficult because there are a limited people in Nigeria with PPP experience hence the use of industry experts for a focus group.

\section{Conclusions}

Stakeholders have an overwhelming influence on the outcome of PPP projects. Several PPP projects, particularly those in low and middle-income countries have failed due to stakeholders' opposition. This has made it imperative to manage external stakeholders with a more effective and structured process to ensure their support.

A few studies have proposed strategies for managing stakeholders within the PPP context albeit only partial processes. This paper advances current practice by developing a framework that places emphasis on how external stakeholder's interests can be systematically identified and addressed. It was developed by synthesising findings from literature and two case studies in Nigeria on stakeholder management on PPP projects. The framework provides an understanding of the roles and responsibilities of internal stakeholders in managing external stakeholders' needs. It offers clarity in managing external stakeholders at the different PPP project phases. The framework provides six steps that together promote a partnership relationship between internal and external stakeholders throughout the PPP project phases. These are: (1) Determine the purpose of stakeholder management; (2) Identify stakeholders; (3) Determine external stakeholders' interests; (4) Develop a communications strategy; (5) Determine capability building strategies; and (6) Evaluate the stakeholder management processes. The framework was validated by industry experts via focus group meetings. This was judged to be complete, user friendly, relevant and practical to address external stakeholder management issues in PPP projects. The framework will aid industry professionals in both the public and private sectors to promote good relationships between stakeholders that is required to enhance success of projects.

\section{References}

Al-Khafaji, A.W., Oberhelman, D.R., Baum, W. and Koch, B. (2010), "Communication in Stakeholder Management", Chinyio, E. and Olomolaiye, P. (eds.) Construction Stakeholder Management. Wiley- Blackwell, Oxford. 
Amadi, C., Carrillo, P., Tuuli, M. (2014), "Stakeholder Management in Public Private Partnership Projects in Nigeria: Towards a Research Agenda", Raiden, A B and Aboagye-Nimo, E (Eds) Procs 30th Annual ARCOM Conference, 1-3 September 2014, Portsmouth, UK, Association of Researchers in Construction Management, pp. 423-432.

Amaeshi, K. (2010), Stakeholder Management: Theoretical Perspectives and Implications. In Chinyio, E. and Olomolaiye, P. (eds.) Construction Stakeholder Management, WileyBlackwell Publishing, Oxford, pp.13-40.

Bourne, L. and Walker, D.H. (2006), "Using a Visualising Tool to Study Stakeholder Influence Two Australian Examples", Journal of Project Management, Vol. 37 No. 1, pp. 5-21.

Bryman, A. (2008), Social research methods, $3^{\text {rd }}$ ed. Oxford University Press, United Kingdom.

Carrillo, P.M., Robinson, H.S., Anumba, C.J. and Bouchlaghem, N.M., (2006), "A Knowledge Transfer Framework: The PFI Context", Construction Management and Economics, Vol. 24 No. 10, pp.1045-1056.

Chinyio, E. \& Akintoye, A. (2008), "Practical Approaches for Engaging Stakeholders: Findings from the UK", Construction Management and Economics, Vol. 26 No. 6, pp. 591-599.

Chinyio, E. and Olomolaiye, P. (2010), "Introducing Stakeholder Management", Chinyio, E. and Olomolaiye, P. (eds.) Construction Stakeholder Management, Wiley- Blackwell, Chichester.

Cleland, D.I. and Ireland, L.R. (2007) Project Management: Strategic Design and Implementation, $5^{\text {th }}$ ed. McGraw- Hill, London.

Close, R. and Loosemore, M. (2014) "Breaking down the site hoardings: attitudes and approaches to community consultation during construction", Construction Management and Economics, Vol. 32 No. 7-8, pp.816-828.

De Schepper, S., Dooms, M. \& Haezendonck, E. (2014), "Stakeholder dynamics and responsibilities in Public-Private Partnerships: A mixed experience", International Journal of Project Management, Vol. 32 No. 7, pp. 1210-1222.

Donaldson, T., and Preston, L. E. (1995), "The stakeholder theory of the corporation: Concepts, evidence, and implications", Academy Management Review, Vol. 20 No. 1, pp. 65-91.

Eisenhardt, K. M. (1989) "Building Theories from Case Study Research", Academy of Management Review, Vol. 14 No. 4, pp.532-550. 
El-Gohary, N., Osman, H. \& El-Diraby, T. (2006), "Stakeholder Management for Public Private Partnerships", International Journal of Project Management, Vol. 24 No. 7, pp. 595-604.

Elias, A. A., Cavana, R. Y. and Jackson, L. S. (2002), "Stakeholder analysis for R and D project management." $R$ and $D$ Management, Vol. 32 No. 4, pp.301-310.

Freeman, R. E. (1984), Strategic Management: A Stakeholder Approach, Pitman, Boston, (MA); London.

Friedman, A. and Miles, S. (2002), "Developing Stakeholder theory". Journal of Management Studies, Vol. 39 No 1, pp. 1-21

Hansford, P. (2018), “Major Projects Must Put Customers First”, New Civil Engineer, April, pp 3.

Henjewele, C., Fewings, P. \& Rwelamila, P.D. (2013), "De-marginalising the Public in PPP Projects Through Multi-Stakeholders Management", Journal of Financial Management of Property and Construction, Vol. 18 No. 3, pp. 210-231.

HM Treasury (2018) Public Private Finance Initiative and Private Finance 2 projects: 2017 summary data. HM Treasury.

Hodge, C. and Greve, C. (2007) Public - Private Partnerships: An International Performance Review. Public Administration Review., Vol. 67 No. 3, pp. 545-558

Joyner, K. (2007), "Dynamic Evolution in Public-Private Partnerships: The Role of Key Actors in Managing Multiple Stakeholders", Managerial Law, Vol. 49 No. 5/6, pp. 206217.

Karlsen, J.T. (2002), "Project Stakeholder Management", Engineering Management Journal, Vol. 14 No. 4, pp. 19- 24.

Manowong, E. and Ogunlana, S. (2010), "Strategies and Tactics for Managing Construction Stakeholders", Chinyio, E. and Olomolaiye, P. (eds.) Construction Stakeholder Management, Wiley- Blackwell, Oxford.

National Audit Office (2009), Performance of PFI Construction, National Audit Office.

National Audit Office (2018) PFI and PF2. National Audit Office.

Newcombe, R. (2003), "From client to Project Stakeholders: A Stakeholder Mapping Approach", Construction Management and Economics, Vol. 21 No. 8, pp. 841-848. 
Ng, S.T., Wong, J.M. \& Wong, K.K. (2013), "A Public Private People Partnerships (P4) Process Framework for Infrastructure Development in Hong Kong", Cities, Vol. 31 2013, pp. 370-381.

Njoku, J., Akoni, O. and Adelaja, B. (2011), "Lekki: Protests, traffic crisis as tolling begins" https://www.vanguardngr.com/2011/12/toll-crisis-traffic-snarl-as-tolling-begins/. Date assessed: 24/04/2018.

Okocha, C., Andrews, J. Isiguzo, J., Oyeyipo, S. Oghifo, B. and Efeizomor, V. (2014), "Nigeria: Jonathan - New Niger Bridge Will Boost South-East Economy" available at http://allafrica.com/stories/201403110243.html (accessed 08/12/2017).

Olander, S. (2007), "Stakeholder Impact Analysis in Construction Project Management", Construction Management and Economics, Vol. 25 No. 3, pp. 277-287.

Olobo, C. (2016) Plugging Africa's infrastructure gap through public private partnerships in Infrastructure Finance in Africa. Capital Markets in Africa.

Organisation for Economic Cooperation and Development (2007), OECD Principles for Private Sector Participation in Infrastructure, Paris.

Osei-Kyei, R. and Chan, A. (2016), Developing Transport Infrastructure in Sub-Saharan Africa through Public-Private Partnerships: Policy Practice and Implications, Transport Reviews, Vol. 36 No. 2, pp. 170-186.

Osei-Kyei, R. and Chan, A. (2018) Stakeholders' Perspectives on the Success Criteria for Public-Private Partnership Projects, International Journal of Strategic Property Management, Vol. 22 No. 2, pp. 131-142.

Proverbs, D. and Gameson, R. (2008), "Case Study Research”, Knight, A. and Ruddock, L. (eds), Advanced research methods in the built environment, John Wiley and Sons, Chichester.

Robson, C. (2011), Real World Research: A Resource for users of social research methods in applied settings, Wiley, Chichester.

Rowlinson, S., Koh, T.Y. and Tuuli, M.M. (2010), "Stakeholder Management in the Hong Kong Construction Industry", Chinyio, E. and Olomolaiye, P. (eds.) Construction Stakeholder Management. Wiley- Blackwell, Oxford.

Rwelamila, P.D. (2010), “Impact of Procurement on Stakeholder Management", Chinyio, E. and Olomolaiye, P. (eds.), Construction Stakeholder Management, Wiley-Blackwell Publishing, Oxford, pp.193-215. 
Rwelamila, P.D., Fewings, P. \& Henjewele, C. (2014), "Addressing the missing link in PPP Projects: What constitutes the public?", Journal of Management in Engineering, Vol. 31 No. 5 , pp. 1-9.

Smyth, H. and Edkins, A. (2007), "Relationship Management in the Management of PFI/PPP Projects in the UK", International Journal of Project Management, Vol. 25 No. 3, pp. 232-240.

South, A.J., Levitt, R.E. and Dewulf, G. (2015), "Dynamic Stakeholder Networks and the Governance of PPPs", Proceedings of the 2nd International Conference on PublicPrivate Partnerships, Austin, Texas, U.S.A.

Sutterfield, J., Friday-Stroud, S., and Shivers-Blackwell, S. (2006), "A Case Study of Project and Stakeholder Management Failures: Lessons Learned", Project Management Journal, Vol. 37 No. 5, pp.26-35.

Whitelaw, J. (2018), “Share and Care”, New Civil Engineer, April, pp. 32-33.

Wilkinson, S. (1998), "Focus group methodology: a review, International Journal of Social Research Methodology", International Journal of Social Research Methodology, Vol. 1 No 3, pp.181-203

World Bank Group (2016), 2016 World Development Indicators, World Bank Group, Washington.

World Health Organisation (2008), Advocacy, Communication and Social Mobilization for TB Control: A Guide to Developing Knowledge, Attitudes and Practice Surveys, Publications of World Health Organisation, Switzerland.

Yang, R.J. and Shen, G.Q. (2015), "Framework for stakeholder management in construction projects", Journal of Management in Engineering, Vol. 31 No. 4, pp.1-14.

Yin, R.K. (2014), Case study research: Design and Methods. $5^{\text {th }}$ ed. Sage, Los Angeles.

Zou, W., Kumaraswamy, M., Chung, J. and Wong, J. (2014), "Identifying the Critical Success Factors for Relationship Management in PPP Projects", International Journal of Project Management, Vol. 32 No. 2, pp. 265-274. 